\title{
On the Applicability of the Arm's Length Principle in Setting Transfer Price: Bangladesh Perspective
}

\author{
Ranjan Kumar Mitra, Mohammed Moin Uddin Reza, Ranjita Islam \\ ${ }^{I}$ (Assistant Professor in Accounting, Department of Accounting \& Information Systems, University of Dhaka, \\ Bangladesh) \\ ${ }^{2}$ (Lecturer in Accounting, Department of Accounting \& Information Systems, Bangladesh University of \\ Professionals, Bangladesh) \\ ${ }^{3}$ (Lecturer in Accounting, Department of Accounting \& Information Systems, Bangladesh University of \\ Professionals, Bangladesh)
}

\begin{abstract}
The rampant misuse of transfer pricing by multinational corporations (MNCs) to maneuver funds internationally and its adverse economy wide implications have attracted the attention of many governments and they have responded to tackle this issue by introducing counter measures which require the application of arm's length principle (ALP) in computing appropriate transfer price. This paper is an attempt to identify how MNCs can misuse transfer price to shift profit from one country to another, how adherence to arm's length principle can act as a partial deterrent to this detrimental initiative, the advantages and problems associated with different methods of determining arm's length price and some solutions to tackle this issue. It is suggested here that since achieving a precise and accurate arm's length price is not always feasible, proper and authenticate documentation of any transfer price employed and its underlying rationale is important.
\end{abstract}

Keywords: Transfer Pricing, Arm's Length Principle, Transactional Method, Transactional Profit Method, Controlled Transaction, Tax

\section{Introduction}

Transfer mispricing is a global economic phenomenon and it has been on the rise in recent years in view of the fast globalizing world of commerce and business. Mispricing takes place in various forms such as mispriced international trade, misquoted contract value, misvalued intangibles, disproportioned cost-sharing in joint projects, and fictitious and overvalued management service. Transfer mispricing distorts the financial integrity of a country by promoting tax evasion, capital flight and money laundering, and creating shadow economy (CPD WP, 2011). A sizeable number of countries have already adopted transfer pricing regime to combat transfer mispricing. Evidence bears out that an increasing number of countries are coming under the shield of transfer pricing regime every year. About 60 countries have already adopted transfer pricing regime. With a view to provide a detailed statutory framework which can lead to computation of reasonable, fair and equitable profits and tax in Bangladesh, the Finance Act, 2012 introduced law of transfer pricing in Bangladesh through sections 107A to $107 \mathrm{~J}$ of the Income tax Ordinance, 1984. The common fact is that transfer pricing rules of every country accept that an appropriate and justifiable transfer price should be calculated with regard to arm's length price to mitigate the consequence of transfer mispricing and to curb multinational companies' ill motive of engaging into deleterious profit shifting activities. The rules also prescribe different methods of calculating arm's length price, the application of which is cumbersome and requires use of judgment that may not be accepted by the counter party. The calculation is also complicated by the fact like non-availability of data or basis for adjustment of functions and risk, selection of comparable companies with same risk and functions or adjustment for stability of result and uneven result of comparable companies. With this background, this paper is an attempt to identify how MNCs can misuse transfer price to shift profit from one country to another, how adherence to arm's length principle can act as a deterrent to this detrimental activity, the advantages and problems associated with different methods of determining arm's length price and some solutions to tackle this issue. It is suggested that since achieving a precise and accurate arm's length price is not always possible, documentation of any transfer price employed and its underlying rationale is important. The type of information and the type of documents that may contain such information are also prescribed.

\section{Objectives Of The Research}

The objective of this paper is to shed light on transfer pricing related issues such as misuse of transfer pricing by MNCs to evade tax, use of arm's length price to determine valid transfer price for international transactions between associated enterprises, necessity of adopting transfer pricing regulation in Bangladesh, suitability of different methods of determining arm's length price and to prescribe some suggestions that are likely to facilitate the use of arm's length price in determining appropriate transfer price and the administration 
On The Applicability Of The Arm's Length Principle In Setting Transfer Price: Bangladesh ..

of the procedure in Bangladesh. The paper highlights that determining the arm's length price by applying the transfer pricing regulation is either not easy because of practical issues discussed or assesses need to take care while entering into transactions with associated enterprises.

\section{The Arm's Length Principle In Setting Transfer Price}

Transfer pricing sets the prices at which the transnational corporate group trades goods and services among its affiliates. Transfer price is the price that the transnational corporation chooses for the valuation of goods, services, know-how, and intellectual property exchanged among different divisions or affiliates under its ownership or control. Transfer pricing provides opportunities for lucrative profit-shifting activities. The simple example given in table below illustrates how the transnational corporation can secure higher after-tax profit through transfer pricing due to differences in corporate tax rates in different jurisdictions. Here a vertically integrated transnational corporation's parent is domiciled in a high-tax country ( 20 percent). It has a foreign affiliate in a low tax country (10 percent). In case 1, a component is produced by the affiliate at a cost of Tk. 800 and is sold to the parent company at the transfer price of Tk. 1,000, which is part of the parent company's cost of goods sold. The parent incurs an additional cost of tk. 600 to transform the good that is sold at Tk. 3,000. Tax liabilities of the transnational corporation are calculated using the before-tax incomes of the parent company and its affiliate. The resulting tax liability is Tk. 300. In case 2, the component produced by the affiliate is sold to the parent company at the transfer price of Tk. 1,500 instead of Tk. 1,000. The parent incurs the same additional cost to transfer the good that is also sold at the same price as in case 1. While there is no effect on total revenue, costs, and pre-tax income of the transnational corporation, there is a net reduction of Tk. 50 of its overall tax liability, resulting in a Tk. 50 increase in its after-tax profit in case 2. These cases demonstrate how the transnational corporation can increase its profit by shifting income from high-tax to lowtax countries through transfer pricing if the corporation is able to arbitrarily set its transfer prices.

\begin{tabular}{|c|c|c|c|}
\hline \multicolumn{4}{|c|}{ Case 1} \\
\hline & Affiliate & Parent & Total \\
\hline Sales & 1,000 & 3,000 & 3,000 \\
\hline Less: Cost of goods sold & 800 & 1,000 & 800 \\
\hline Less: Additional costs & & 600 & 600 \\
\hline Profit before tax & 200 & 1,400 & 1,600 \\
\hline Tax & 20 & 280 & 300 \\
\hline Profit after tax & 180 & 1,120 & 1,300 \\
\hline \multicolumn{4}{|c|}{ Case 2} \\
\hline Sales & 1,500 & 3,000 & 3,000 \\
\hline Less: Cost of goods sold & 800 & 1,500 & 800 \\
\hline Less: Additional costs & & 600 & 600 \\
\hline Profit before tax & 700 & 900 & 1,600 \\
\hline Tax & 70 & 180 & 250 \\
\hline Profit after tax & 630 & 720 & 1,350 \\
\hline
\end{tabular}

As a counter measure to detrimental profit shifting activity of MNCs, the arm's length principle provides the foundation for setting an appropriate transfer price for transactions with affiliates. Arm's length principle considers the price derived in an uncontrolled transaction as a proxy for a price in a controlled transaction. Controlled transaction is a transaction between related parties, whereas uncontrolled transaction is either between two unrelated parties or between a related party and unrelated party. Transactions for same or similar goods and services between unrelated parties or between related and unrelated parties are used to determine the "arm's length" price for a transaction among related parties.

The arm's length principle is the only internationally accepted basis for transfer pricing methods. According to OECD (2001): "[When] conditions are made or imposed between the two enterprises in their commercial or financial relationships which differ from those which would be made between independent enterprises, then any profits which would, but for those conditions, have accrued to one of the enterprises, but by reason of those conditions, have not so accrued, may be included in the profits of that enterprise and tax accordingly." When unrelated enterprises deal with each other, open market conditions generally determine the commercial and financial relationships and dealings. The objective of transfer pricing methodology is to determine the prices at which goods and intangibles are exchanged among affiliates within a transnational corporate group.

According to $\operatorname{OECD}(1979,1984,1987$, and 2001) guidelines, transfer pricing must be based on the arm's length principle which states that exchanges among related parties should be set by reference to conditions which would have obtained between independent enterprises in comparable transactions and comparable circumstances. The arm's length principle treats the affiliates of the transnational corporate group as if they were independent enterprises. Suppose company A and company B both belongs to the same transnational corporate group. Company A sells an intermediate good to company B. Hence, under the arm's 
length principle, company A should charge company B what it should have charged if it were an independent enterprise not connected in any way with company A.

From the discussion it follows that use of arm's length price in international transaction could mitigate the problem of profit shifting activities as showed in the example and thus reduce loss of tax. Hence, the tax authorities should rely on arm's length price as the appropriate transfer price to be used by corporations when pricing for transfer of goods or services to their affiliated entities. But the issue is complicated by the fact that there are different methods available to calculate arm's length price and each method will produce different price when applied to a single transaction. The question then arises as to which method will be followed or which price will be accepted by the taxing authority.

\section{Different Methods Of Determining Arm's Length Price}

Transfer pricing methods are techniques or procedures used for determining the arm's length price and estimating the amount of adjustment. When a transaction is not at arm's length, tax officials reject the disclosed price of that transaction, and calculate its arm's length price. Tax officials do not assign arbitrary value to the transaction; they instead follow one or more generally accepted methods to determine the arm's length price. There are several different methods for establishing arm's length price. These can be classified into three categories as follows: (a) Transactional methods; (b) Transactional profit methods; and (c) Unconventional methods. These methods are in line with OECD guidelines.

\section{a. Transactional Methods}

Transactional methods are the most direct and effective means of establishing transfer price based on the arm's length principle. Transaction based methods are the preferred methods of establishing transfer pricing. Three transactional methods are used for transfer pricing. These are described below.

\section{The Comparable Uncontrolled Price Method (CUP)}

The comparable uncontrolled price method compares the price charged for property or services transferred in a controlled transaction to the price charged for property or services transferred in a comparable uncontrolled transaction in comparable circumstances. If there is any difference between the two prices, this may indicate that the conditions of the commercial and financial relations of the associated enterprises are not arm's length, and that the price in the uncontrolled transaction may need to be substituted for the price in the controlled transaction. The comparable uncontrolled price method can be applied on the basis of the taxpayer's transactions with independent enterprises (internal comparables), or on the basis of transactions between other independent enterprises (external comparables).

Although this method is potentially available for all types of transactions, the product comparability requirement to be able to apply it in a reasonably reliable manner is especially high, because any product difference may materially affect the price of the transaction while it is often not practicable to determine reasonably accurate comparability adjustments for such product differences. In the absence of internal comparables, the CUP method is therefore most helpful for establishing an arm's length price for a) sales of commodities traded on a market, subject to the controlled transaction and comparable uncontrolled transaction(s) taking place in comparable circumstances, including at the same level of the commercial chain (e.g. sale to a secondary manufacturer, to a distributor, to a retailer, etc.), and b) some common financial transactions, such as the lending of money. Market prices (such as commodity prices or rates of interest) may be publicly available for these types of transactions.

\section{The Resale Price Method}

The resale price method begins with the price at which a product that has been purchased from an associated enterprise is resold to an independent enterprise. This price (the "resale price") is then reduced by an appropriate gross margin (the "resale price margin"), determined by reference to gross margins in comparable uncontrolled transactions, representing the amount out of which the reseller would seek to cover its selling and other operating expenses and, in light of the functions performed (taking into account assets used and risks assumed), make an appropriate profit. What is left after subtracting the gross margin can be regarded, after adjustment for other costs associated with the purchase of the product (e.g. customs duties), as an arm's length price for the original transfer of property between the associated enterprises.

This method is probably most useful where it is applied to sales and marketing operations such as those typically carried out by a distributor. In some circumstances, the resale price margin of the reseller in the controlled transaction may be determined by reference to the resale price margin that the same reseller earns on items purchased and sold in comparable uncontrolled transactions (an internal comparable). In other circumstances the resale price margin may be determined by reference to the resale price margin earned by independent enterprises in comparable uncontrolled transactions (external comparables). 
On The Applicability Of The Arm's Length Principle In Setting Transfer Price: Bangladesh ..

\section{The Cost plus Method}

The cost plus method begins with the costs incurred by the supplier of property or services in a controlled transaction for property transferred or services provided to an associated enterprise. An appropriate mark up, determined by reference to the mark up earned by suppliers in comparable uncontrolled transactions, is then added to these costs, to make an appropriate profit in light of the functions performed and the market conditions. Such arm's length mark up may be determined by reference to the mark up that the same supplier earns in comparable uncontrolled transactions (an internal comparable), or by reference to the mark up that would have been earned in comparable transactions by an independent enterprise (external comparable). In general, the cost plus method will use margins computed after direct and indirect costs of production or supply, but before the operating expenses of the enterprise (e.g. overhead expenses).

This method probably is most useful where (a) goods are sold by a manufacturer that does not contribute valuable unique intangible assets or assume unusual risks in the controlled transaction, such as may be the case under a contract or toll manufacturing arrangement; or (b) where the controlled transaction is the provision of services for which the provider does not contribute any valuable unique intangible assets or assume unusual risks.

\section{b. Transactional Profit Method}

Though transaction based methods are the preferable means of obtaining transfer prices for intra-firm transactions, there are often practical difficulties in applying transaction methods. When no data are available, or available data are insufficient or of questionable quality, it may be necessary to resort to transactional profit methods. Transactional profit methods examine the profit that arises from particular controlled transactions. Profit arising from controlled transactions can be an indicator of whether the transaction was affected by conditions that differ from those that would have been made by unrelated parties in otherwise comparable circumstances. The application of the transactional profit methods can provide an approximation of transfer pricing in a manner consistent with the arm's length principle. There are two transactional profit methods used for transfer pricing. These are described below.

\section{The Transactional Net Margin Method}

The transactional net margin method seeks to equate the net profit margin relative to an appropriate base (e.g. costs, sales, assets) that a taxpayer realizes from a controlled transaction (or from transactions that are appropriate to aggregate and consider together) with the net profit margin earned in comparable uncontrolled transactions. The arm's length net margin of the taxpayer from the controlled transaction(s) may be determined by reference to the net margin that the same taxpayer earns in comparable uncontrolled transactions (internal comparables), or by reference to the net margin earned in comparable transactions by an independent enterprise (external comparables).

In cases where the net profit margin is weighed against costs or sales, the transactional net margin method operates in a manner similar to the cost plus and resale price methods respectively, except that it compares the net profit margins arising from controlled and uncontrolled transactions (after relevant operating expenses have been deducted) instead of comparing a gross margin on resale or gross mark up on costs.

\section{The Transactional Profit Split Method}

The transactional profit split method first identifies the profit to be split for the associated enterprises from the controlled transactions in which the associated enterprises are engaged. The combined profit may be the total profit from the transactions, or a residual profit intended to represent the profit that cannot readily be assigned to one of the parties from the application of another transfer pricing method such as the profit arising from high-value, unique intangibles. Note that the combined profit may be a loss in some circumstances.

The transactional profit split method then splits that profit between the associated enterprises on an economically valid basis that approximates the division of profits that would have been anticipated between independent enterprises. This economically valid basis may be supported by independent market data (e.g. uncontrolled joint-venture agreements) or by internal data. The types of such internal data that are relevant will depend on the facts and circumstances of the case and may include, for example, allocation keys relating to the respective sales, research and development expenses, operating expenses, assets or headcounts of the associated enterprises. The splitting factor should reflect the respective contributions of the parties to the creation of income from the controlled transaction and be reasonably independent from transfer pricing formulation (i.e. it should be based on objective data (such as sales to unrelated parties), not on data relating to the remuneration of controlled transactions (such as sales to associated enterprises). 
On The Applicability Of The Arm's Length Principle In Setting Transfer Price: Bangladesh ..

\section{c. Unconventional Methods}

The authorities often resort to unconventional methods for transfer pricing when other methods are not applicable. There are two unconventional techniques used for transfer pricing that are worth mentioning. These are as follows: (a) advanced pricing agreement and (b) global formulary apportionment method.

\section{Advanced Pricing Agreement}

Advanced pricing agreement is an arrangement that determines, prior to a transaction among related parties, appropriate criteria for the determination of the transfer prices for those transactions over a fixed period of time. Advance pricing agreement can be unilateral, bilateral, or multilateral. These agreements are initiated by a transnational corporation and require negotiations between the taxpayers, that is, the affiliates involved, and the tax authorities concerned. These agreements supplement conventional mechanisms for resolving transfer pricing issues, and are often useful when conventional methods are difficult to apply. Such agreements have numerous advantages, such as the elimination of uncertainty in tax treatment of cross-border transactions, the creation of non-adversarial relations between the taxpayer and the authorities, the reduction of costs, and so on.

\section{Global Formulary Apportionment Method}

Global formulary apportionment method is a method to allocate the global profits of the transnational corporation on a consolidated basis among its associated affiliates in different countries on the basis of a predetermined formula. There are three essential components to the application of this method: determining the unit to be taxed; accurately determining the global profits; and establishing the formula to be used to allocate the global profits of the unit. The formula is based on costs, assets, payroll, sales, or some combination of these. Formulary apportionment is not based on the arm's length principle. There are many complex and practical problems that prevent it from developing a complete solution to the allocation of profits in a transnational corporate group. OECD (2000) explicitly rejects global formulary apportionment as a method for determining the proper level of profits across national tax jurisdictions.

Most of the countries that have adopted transfer pricing regulation allow corporations to apply any one of the above mentioned methods to compute appropriate transfer price considering the suitability of any method for a particular type of transactions.

\section{Rationale For Adopting Transfer Pricing Rules In Bangladesh}

Transfer mispricing is a global economic phenomenon and it has been on the rise in recent years in view of the fast globalizing world of commerce and business. Not surprisingly, evidence suggests that LDCs such as Bangladesh are not immune to this economic malaise. The estimates are not negligible, and have been on the rise in the recent past. An international study finds that, between 2005 and 2007, Bangladesh lost about USD 359 million of tax revenue due to mispricing in trade with the EU 27 and US alone. In the same period, as some of the studies indicate, Bangladesh experienced a capital outflow to the tune of USD 1.19 billion due to mispricing in connection with her bilateral trade with US and EU 27 countries. Given the fact that Bangladesh has only one-third of her global trade with EU 27 and US, and other trade partners account for the rest two-thirds, there is no doubt that the actual loss of tax and capital for Bangladesh due to trade mispricing is much higher than is indicated by the estimates presented in the aforesaid studies (CPD Working Paper: 94).

Bangladesh lacks proper institutional capacity to track, mine and monitor cross-border transactions, identify mispricing, detect capital flight, and recover tax and capital. Therefore, the country is in the high-risk zone from the perspective of transfer pricing abuse. Bangladesh has witnessed a 142 per cent rise in the volume of international trade in the period between 2004 and 2009. This increasing trend in the volume of international trade has also created an environment where the risks of losing tax and capital have been on the rise. Being a large consumer market of over 150 million people, Bangladesh is a lucrative field for multinational operation. Hundreds of enterprises having multinational interest are operating at present in the country. This number is likely to increase further in future. The presence of multinational operation in Bangladesh exposes the country's tax system to the risk of transfer pricing abuse.

Intra-firm transaction is a common weapon in the arsenal of multinational companies used for transfer mispricing. Bangladesh is trying to attract more foreign direct investment, increase its exports and particularly develop its energy and infrastructure sectors. With more foreign direct investment in energy and infrastructure sectors, the level of intra-firm transactions is bound to rise. Multinational corporations' economic activity can benefit developing countries by providing technology, capital, management, skills, proprietary know-how, access to global markets, and international best practices if the host country's policy framework is prudential. Even though multinational corporations have a lot of beneficial effects on the economy, the effects of their activities are not solely benign. It is possible that transnational corporations can have harmful effects on the economy if they are able to engage in profit-shifting activities and unfair competition with indigenous firms. Transfer pricing offers lucrative avenues for profit-shifting activities and tax avoidance. In a corrupt business 
and bureaucratic environment, a multinational corporation's scope of engaging in profit-shifting activities and malfeasance is further magnified.

Bangladesh has significantly high rate of corporate taxation than many developed and developing countries. The high rate of corporate taxation makes Bangladesh relatively more vulnerable to the risk of profit transfer. Moreover, variation in tax rates for different categories of corporate taxpayer coupled with tax exemptions and other forms of tax incentives to selective categories of taxpayers have also created a breeding ground for transfer mispricing by domestic companies leading to significant revenue erosion each year. Given the already existing presence of multinational corporations and the likelihood of increased foreign investment in the country, Bangladesh government has adopted transfer pricing rules to secure tax revenue by extending its tax base, to ensure that multinational corporate presence in the country are not used as guises for profit-shifting activities and tax-fencing transactions, to minimize loss of tax and to discourage flight of capital from the country.

\section{Arm's Length Price: Bangladesh Perspective}

Increasing participation of multi-national groups in economic activities in Bangladesh has given rise to new and complex issues emerging from transactions entered into between two or more enterprises belonging to the same group. Hence, there was a need to introduce a uniform and internationally accepted mechanism of determining reasonable, fair and equitable profits and tax in Bangladesh in the case of such multinational enterprises. Accordingly, the Finance Act, 2012 introduced law of transfer pricing in Bangladesh through sections 107A to 107J of the Income tax Ordinance, 1984. Section 107C of the said Ordinance covers the detailed calculation of transfer price using arm's length principle. In accordance with internationally accepted principles, the transfer pricing rules have provided that any income arising from an international transaction between associated enterprises shall be computed having regard to the Arm's Length Price, which is the price that would be charged in the transaction if it had been entered into by unrelated parties in similar conditions. The Arm's Length Price is to be determined by any one or more of the prescribed methods. The prescribed methods have been listed below:

(a) Comparable Uncontrolled Price Method

(b) Resale Price Method

(c) Cost plus method

(d) Profit Split Method

(e) Transactional Net Margin Method

(f) Such other method as may be prescribed by the Board

The present transfer pricing rules seem to be deficient in certain aspects related to use of Arm's Length Price. The taxpayer can select the most appropriate method to be applied to any given transaction, but such selection has to be made taking into account the factors prescribed in the rules. In addition the taxpayer could consider other factors like the nature and class of the international transaction; the class or classes of associated enterprises entering into the transaction and the functions performed by them taking into account assets employed or to be employed and risks assumed by such enterprises; the availability, coverage and reliability of data necessary for application of the method; the degree of comparability existing between the international transaction and the uncontrolled transaction and between the enterprises entering into such transactions; the extent to which reliable and accurate adjustments can be made to account for differences, if any, between the international transaction and the comparable uncontrolled transaction or between the enterprises entering into such transactions; the nature, extent and reliability of assumptions required to be made in application of a method. The most appropriate method will be the method which is best suited to the facts and circumstances of each particular international transaction, and which provides the most reliable measure of an arm's length price in relation to an international transaction.

\section{Some Suggestions To Facilitate Determination Of Arm's Length Price}

Achieving a precise and accurate arm's length price is not always possible. Hence, documentation of any transfer price employed and its underlying rationale is important. The following steps will be helpful in setting transfer prices.

- Analyze the risks assumed and functions performed by the affiliated companies and the economic and legal determinants that affect pricing.

- Identify and analyze benchmark companies and transactions; document reasons for any adjustments made

- Compare the financial results of the comparable companies to that of the tax payer.

- If comparable transactions are available, note their similarities and differences with the taxpayer's transactions.

- Document why the chosen pricing method is the most reasonable and why the other methods are not.

- Update the information prior to filing the tax return 
The OECD also emphasizes the importance of the functional analysis in determining the arm's length price and identifying suitable entities for comparison purpose. The analysis of functions, risks and assets is expected to create some practical difficulties like (i) Availability of data or basis for adjustment of functions and risk, (ii) Selection of comparable companies with same risk and functions, (iii) Adjustment for stability of result and uneven result of comparable companies. Also where assessees make adjustment for risk, the tax officials may not agree on working or basis, so it will become more judgmental. Hence some rules or guidelines for making these adjustments should be designed so that these adjustments can be carried out which will make it easy to determine the arm's length price.

To facilitate the calculation of arm's length price and to substantiate the rationale during transfer pricing audit, the companies should be required to maintain appropriate information documents and be prepared to authenticate and file such documentation for examination and audit by the authorities. Companies should be required some or all of the following types of information:

1) A general description of the organizational, legal, and operational structure of the group of associated enterprises of which the taxpayer is a member, as well as any relevant change therein during the taxable period.

2) The group financial report or equivalent annual report for the most recent accounting period.

3) A description of the group's policy in the area of transfer prices, if any.

4) A general description of the nature and value of the controlled transactions in which the taxpayer is involved or which have an effect on the income of the taxpayer.

5) A description of the functions, assets and risks of group companies to the extent that they affect or are affected by the controlled transactions carried out by the taxpayer, including any change compared to the preceding period.

6) With respect to each material controlled transaction carried out by the taxpayer, a description of the transfer pricing method used by the taxpayer to demonstrate that the prices and other financial indicators associated with the transaction satisfy the requirements of the arm's length principle and a description of why such methods are the most appropriate transfer pricing methods.

7) A record of uncontrolled transactions taken into account for analyzing their comparability with the international transactions entered into, including a record of the nature, terms and conditions relating to any uncontrolled transaction with third parties which may be of relevance to the pricing of the international transactions;

8) A record of the analysis performed to evaluate comparability of uncontrolled transactions with the relevant international transaction;

9) A record of the actual working carried out for determining the arm's length price, including details of the comparable data and financial information used in applying the most appropriate method, and adjustments, if any, which were made to account for differences between the international transaction and the comparable uncontrolled transactions, or between the enterprises entering into such transactions;

10) The assumptions, policies and price negotiations, if any, which have critically affected the determination of the arm's length price.

The information requirements mentioned above should be supported by authentic documents, which may include the following:

a) official publications, reports, studies and data bases from the Government of the country of residence of the associated enterprise, or of any other country;

b) reports of market research studies carried out and technical publications brought out by institutions of national or international repute;

c) price publications including stock exchange and commodity market quotations;

d) published accounts and financial statements relating to the business affairs of the associated enterprises;

e) agreements and contracts entered into with associated enterprises or with unrelated enterprises in respect of transactions similar to the international transactions;

f) letters and other correspondence documenting any terms negotiated between the assessee and the associated enterprise;

g) documents normally issued in connection with various transactions under the accounting practices followed.

Due to its complex nature, determination of arm's length price requires consideration of many variables sometimes beyond managerial control. Therefore, it is suggested that all assumptions made and information used to derive arm's length price should be properly documented and shared with taxing authority to justify the rationale for using such price. 


\section{Conclusion}

In this era of trade globalization, no tax agency can safeguard revenue without the presence of a sound transfer pricing system. Bangladesh as a fast growing economy with increasing exposure to the risk of mispricing in cross-border transactions is no exception. To tackle the issue, Bangladesh has stepped into the world of transfer pricing regulation by incorporating transfer pricing rules in Income tax Ordinance 1984 to combat financial wrongdoings and safeguard the national tax and capital. The Ordinance now requires use of arm's length price to determine transfer price and also prescribes some methods for determining arm's length price. The paper discusses the pros and cons of these methods and comes up with some suggestions to overcome the complexity of calculation. The suggestions are expected to benefit both the tax executives and tax officials in determining transfer price that is acceptable to both parties and in settling any dispute that may arise in future.

\section{References}

[1]. CPD. 2011. Adopting Transfer Pricing Regime in Bangladesh: Rationale and the Needed Initiatives. Working Paper: 94. Dhaka: Centre for Policy Dialogue

[2]. Finance Act 2012. Ministry of Finance. Government of People's Republic of Bangladesh.

[3]. OECD. 1979. Transfer Pricing and Multinational Enterprises. Paris: Organization for Economic Cooperation and Development.

[4]. OECD. 1984. Transfer Pricing and Multinational Enterprises---Three Taxation Issues. Paris: Organization for Economic Cooperation and Development.

[5]. OECD. 1987. Thin Capitalization. Paris: Organization for Economic Cooperation and Development.

[6]. OECD. 2001. Transfer Pricing Guidelines for Multinational Enterprises and Tax Administration. Paris: Organization for Economic Cooperation and Development. 